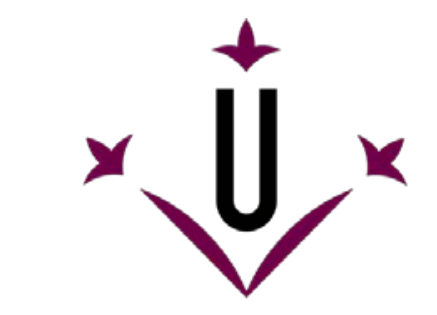

Universitat de Lleida

Document downloaded from:

http://hdl.handle.net/10459.1/60226

The final publication is available at:

https://doi.org/10.1080/13670050.2016.1144709

Copyright

(c) Taylor \& Francis, 2016 


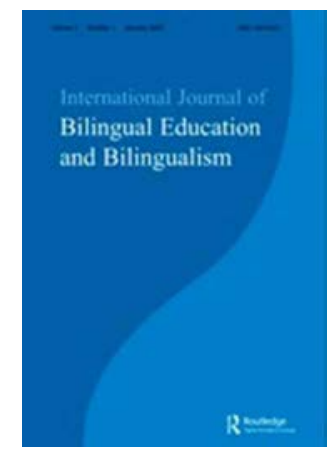

\section{Opening Perspectives from an I ntegrated Analysis: Language Attitudes, Place of Birth and Self-identification}

\begin{tabular}{|c|c|}
\hline \multirow{3}{*}{$\begin{array}{r}\text { Journal: } \\
\text { Manuscript ID } \\
\text { Manuscript Type: }\end{array}$} & International J ournal of Bilingual Education and Bilingualism \\
\hline & BEB-1353.R2 \\
\hline & Paper \\
\hline Keywords: & $\begin{array}{l}\text { Language Attitudes, Self-identification, Catalonia (Spain), Latin-American } \\
\text { Youth, Moroccan Youth }\end{array}$ \\
\hline Abstract: & $\begin{array}{l}\text { There is a theoretical and empirical tradition demonstrating the influence of } \\
\text { the place of birth and self-identification in the shaping of language } \\
\text { attitudes. But very few works analyse their joint effects. The main aim of } \\
\text { this study is to analyse both the disaggregated and joint impact of these } \\
\text { variables on the shaping of attitudes towards Catalan and Spanish } \\
\text { languages in Catalonia. The sample consists of } 309 \text { adolescents (aged 14- } \\
16 \text { years) coming from Ecuador, the rest of Latin America and Morocco. } \\
\text { Both variables have an influence on attitudes towards Catalan separately, } \\
\text { but when analysed jointly in the same explanatory model, self- } \\
\text { identification outweighs place of birth. This is more evident among young } \\
\text { people who develop the most and the least favourable attitudes. } \\
\text { Furthermore, attitudes towards Spanish are only influenced by the place of } \\
\text { birth, and by none of the variables in the case of those with the most and } \\
\text { least favourable attitudes. These results open new lines for research and } \\
\text { reflection on the process of construction of language attitudes and their } \\
\text { role in a successful process of integration. }\end{array}$ \\
\hline
\end{tabular}





\section{Opening Perspectives from an Integrated Analysis: Language Attitudes, Place of Birth and Self-identification}

There is a theoretical and empirical tradition demonstrating the influence of the place of birth and selfidentification in the shaping of language attitudes. But very few works analyse their joint effects. The main aim of this study is to analyse both the disaggregated and joint impact of these variables on the shaping of attitudes towards Catalan and Spanish languages in Catalonia. The sample consists of 309 adolescents (aged 14-16 years) coming from Ecuador, the rest of Latin America and Morocco. Both variables have an influence on attitudes towards Catalan separately, but when analysed jointly in the same explanatory model, self-identification outweighs place of birth. This is more evident among young people who develop the most and the least favourable attitudes. Furthermore, attitudes towards Spanish are only influenced by the place of birth, and by none of the variables in the case of those with the most and least favourable attitudes. These results open new lines for research and reflection on the process of construction of language attitudes and their role in a successful process of integration.

Keywords: Language Attitudes, Self-identification, Latin-American Youth, Moroccan Youth, Catalonia (Spain).

Word Count: 6,125 


\section{Contextualisation and Theoretical Notes}

The Act of Linguistic Normalization, passed in Catalonia in 1983 with the support of the vast majority of the political parties at the time, and that of most of the society, has resulted in the revitalization of the Catalan language. This has happened thanks to: i) its introduction as the vehicular language within the Educational System, through the so called immersion programmes (although strictly speaking these are joint teaching programmes (Vila-Moreno and Galindo 2009); this consolidated the knowledge of the Spanish and Catalan languages, ii) the significant presence of Catalan in the media and iii) the use of Catalan by the Administration (Turell 2001). This Act was initially designed for speakers of two languages, Spanish and Catalan, according to the demographic composition in the 1980s and 1990s, and has become a model to be followed due to its success, both at language learning and language attitudes levels and as the driving force of an ascending social mobility and normalised coexistence (Solé 1981; Woolard and Gang 1990).

However, the current socio demographic composition of the adolescent population in Catalonia has changed significantly, mainly due to the migrations experienced during recent decades. Thus, the non-Spanish population under 19 years of age in Catalonia has increased by $26.73 \%$ during the period 2006-2014, from 188,259 to 238,583 (Spanish Statistical Office 2015). Its origins are diverse, but in the age group 12 to 16 years (which corresponds to Compulsory Secondary Education) most come from Latin America and the Maghreb region. These two areas account for $63.33 \%$ of the total of foreign young people. Ecuadorians account for 25.91\% of Latin Americans, while nearly all Maghreb young people are Moroccan (98.37\%) (Generalitat de Catalunya 2015). 
This had an effect on educational, reception and integration policies. Within the area of education, recent reviews of the Plan for Language and Social Cohesion (Pla per a la Llengua i Cohesió Social), better known as Pla LiC (Generalitat de Catalunya 2007, 2009), had the main aim of 'promoting and consolidating social cohesion, intercultural education and the Catalan language within a multilingual framework’ (Generalitat de Catalunya 2009, 14). In order to achieve this end, a new model of language immersion is promoted in which Reception Classrooms and Environment Educational Plans are reinforced in addition to pedagogical activities adjusted for the classroom.

From a more general perspective, integration policies stress the identification with Catalonia as one of their principles. Within this identitarian project, Catalan should be the backbone of a common and multilingual project of coexistence, including the knowledge of the languages present in Catalonia (Catalan / Spanish / immigrants’ L1) as an element of progress and social mobility (Generalitat de Catalunya 2009, 2013).

But as Lewis (1981) states, the success in the design and implementation of any policy directly or indirectly related to languages is tied to the knowledge of the population's language attitudes. Thus, the effectiveness of a policy would be related to its effect on the attitudes of the actors involved, its capacity to transform the attitudes of those who do not share them and the analysis of the causes behind these attitudes.

Therefore, the analysis of language attitudes transcends the cognitive, affective and behavioural elements that compose them, and connects directly with elements of selfidentification (Garret 2010; Hogg and Smith 2007; name deleted to maintain the integrity of the review process 2010; Tajfel and Turner 1986; Woolard 1991). For 'autochthonous’ people, 
but especially for the descendants of immigrants ${ }^{1}$, such self-identification refers to fundamental aspects such as how they perceive and feel their sense of belonging or not in society, the development or not of bonds of affection with the place, and their attitudes (Haines 2007; name deleted to maintain the integrity of the review process 2010; name deleted to maintain the integrity of the review process 2014; Portes Vickstrom and Aparicio 2012).

Different approaches analysing the role of language in the construction of identity sustain that language attitudes are not a mere marker of identity (Castelan and Giles 1997), but they also become the attribute par excellence of identity itself (Edwards 2009; Fishman 1977; name deleted to maintain the integrity of the review process 2008). Consequently, they reflect belonging, and are mutually tied to ideologies and language preferences (Alarcón and Parella 2013; Trenchs and Newman 2009; Woolard and Schieffelin, 1994).

In this sense, some works that do not specifically focus on how self-identification influences language attitudes, do focus implicitly on closely related processes such as ideologies or language preferences.

At this point it is impossible not to mention Woolard's classic works (1989) and Woolard and Gang's (1990). They were both developed during the 1980s, coinciding with the access to education of the children of immigrants from different parts of Spain received in Catalonia during the 1970s. The first of these works, carried out in 1980, when the process of language normalisation was in an embryonic state, concluded that both the group with a Catalan background and the group with a Spanish background showed a clear preference for their own language in the affective dimension. At the same time, rejection was observed 
towards Spanish speakers whose accent was noticeable when speaking Catalan. The study was repeated seven years later and, although the preference towards one's own language persisted, the perception of the Catalan spoken by Spanish speakers had improved.

Newman, Trenchs and Ng (2008) and Trenchs and Newman (2009) adapted and completed a similar analysis focusing, in that case, on the 'autochthonous' and Latin American groups that had reached Catalonia during the last immigration wave. Their main conclusions suggested that there were differences between the two groups with regards to their language ideologies that would directly affect attitudes towards languages, on the basis of a preference towards multilingualism (Cosmopolitanism) or monolingualism (Parochialism). Moreover, the Latin American collective does not reproduce the exact same pattern followed by Spanish speakers in the 1980s. Although they value the peninsular Spanish as a language of international prestige used in Catalonia and in the rest of Spain, Catalan is also valued as a language of integration and social progress. This is added to the symbolism conferred to their non-peninsular Spanish, tightly connected to their identity (Trenchs and Newman 2009). Newman, Trenchs and Patiño (2012) and Trenchs and Patiño (2013) reached similar conclusions again in a study carried out in three reception classes in Barcelona with Latin American immigrants.

Huguet, Janés and Chireac (2008) administered an attitudes questionnaire to 225 immigrant students in different counties in Catalonia, showing how attitudes towards Catalan and Spanish are mostly positive, although they are modulated by the family language, the origin and the length of stay. Thus, those who had less positive attitudes towards Catalan are those who speak Spanish as an L1, come from Latin America and have been living in Catalonia for the shortest time. Those with the most positive attitudes are those, whose L1 is 
Arabic or Berber, come from the Maghreb and have been in Catalonia for longer. The family’s socio-cultural and socio-economic level did not show relevance.

Name deleted to maintain the integrity of the review process (2010) complement this study with an analysis of the discourses that sustain the language attitudes of migrated people. Their analysis shows these discourses are determined by the aforementioned variables, but point out the condition that the young immigrants identifying themselves more with Catalonia and feeling valued and integrated at school and the society, exhibit better attitudes towards languages, higher competence levels and more balanced patterns of language use. One of the reasons for the development of this self-identification and recognition is the possibility to receive classes of the language and culture of their country of origin.

Finally, in Madariaga, Huguet and Lapresta (2013), 1,206 'autochthonous' and immigrant students in their 2nd and 4th years of secondary education in Catalonia completed a questionnaire on language attitudes. Although attitudes are mostly positive towards Catalan and Spanish, it can be concluded again that, in the case of immigrant students, these vary depending on being Spanish-speaking or not, the family language, the length of stay and the age on arrival. Thus, Spanish speakers, who mostly use Spanish as their L1, show more positive attitudes towards this language than towards Catalan when compared to other groups. In the same way, those born in Catalonia show better attitudes towards Catalan.

As a general trend, all these analyses tend to reveal the significance of origin and the importance of aspects which are interconnected with self-identification. 
At this point it is essential to make a clarification: the results of previous studies show recurring differences between Latin American and others that might infer a similar attitudinal and self-identifying behaviour. But the heterogeneity of this group should certainly not be underestimated. Recent work developed in the Catalan context focusing on language preferences (Alarcón and Parella 2013) and educational expectations (Alarcón, Parella and Yiu 2014), show this variability. In the case of the language preferences towards Catalan, being Ecuadorian predicts a higher preference for other languages, than being Colombian, Argentinean or Chilean, who exhibit very similar values. Equally, Ecuadorians state lower educational expectations than other Latin American groups.

This heterogeneity is also evident in the self-identification with the receiving society. In an analysis about predictors of self-identification with Spain among second-generation teenagers in Madrid and Barcelona, Portes, Celaya, Vickstrom and Aparicio (2012) show that young people coming from Latin America present a differentiated behaviour: being Ecuadorian is a predictor for stronger self-identification with Spain, while being Argentinean, Chilean or Venezuelan is not (again, with very similar scores among them).

With this background and with the aim of advancing the knowledge on the construction of language attitudes of young people descended from immigrants with a greater presence in Catalonia (from Maghreb and Latin America), we need studies with different approaches that can shed new light on how these variables are interlocked.

The impact of self-identification and the place of birth on the language attitudes of young immigrants, whether in isolation or combined has been rarely analysed. That is, given the proven importance attributed to language/s in Catalonia in educational, identitarian and 
welcoming policies, the main objective of this paper is to analyse the impact and interrelation of (i) the place of birth and (ii) self-identification with Catalonia and Spain in language attitudes towards Catalan and Spanish.

We focus on the most important areas of origin and, specifically, on the most prevalent countries of origin (Morocco / Ecuador / Other Latin American countries). Also, in order to make a more in depth analysis of their interrelation, a global analysis is performed, as well as an analysis of the subjects showing the most and least favourable attitudes towards the languages in the study.

\section{Objectives}

The objectives of this paper are:

i) To analyse the impact and interrelation of the place of birth (born in Ecuador / Morocco / Other Latin American countries) and the degree of self-identification with Catalonia and Spain, on the language attitudes towards Catalan and Spanish of these young people in Catalonia.

ii) To analyse the impact and interrelation of place of birth (born in Ecuador / Other Latin American countries / Morocco) and the degree of self-identification with Catalonia and Spain, of young people showing the most favourable language attitudes towards Catalan and Spanish. 
iii) To analyse the impact and interrelation of place of birth (born in Ecuador / Other Latin American countries / Morocco) and the degree of self-identification with Catalonia and Spain, of young people showing the least favourable language attitudes towards Catalan and Spanish.

\section{Methodology}

\section{Participants}

The total sample consists of 309 young people in 10 Secondary Schools in Catalonia. ${ }^{2}$ Their mean age is 14.85 years; $48.90 \%$ (151) are boys and $51.10 \%$ (158) are girls.

Although the objectives in this paper focus on the analysis of language attitudes of young people according to their place of birth and self-identifications, previous analyses of the data show that there are no differences between the groups in function of other variables that in previous studies were found to be significant (Oller 2010; Oller and Vila 2010; Ubalde 2013). Specifically, there are no statistically significant differences with regard to gender $(\mathrm{x} 2=1.697 ; \mathrm{p}=.428)$, grade $(\mathrm{x} 2=12.002 ; \mathrm{p}=.062)$, age $(\mathrm{x} 2=10.446 ; \mathrm{p}=.577)$, length of stay ( $\mathrm{x} 2=1104.344 ; \mathrm{p}=.081)$, bilingual language use in school $(\mathrm{x} 2=6.984 ; \mathrm{p}=.990)$, with friends $(\mathrm{x} 2=4.897 ; \mathrm{p}=.086)$ and with adults $(\mathrm{x} 2=16.057 ; \mathrm{p}=.582)$. Thus, we can safely assume that these variables do not confound the results.

\section{Variables}

The variables considered for our research are: 
*Attitudes towards Catalan: variable with a range between -10 and +10 where -10 is a totally negative attitude, 0 is totally neutral and +10 totally positive.

* Attitudes towards Spanish: variable with a range between -10 and +10 where -10 is a totally negative attitude, 0 is totally neutral and +10 totally positive.

*Place of birth: admits the categories Ecuador / Other Latin American countries ${ }^{3}$ / Morocco.

*Self-identification with Catalonia: admits the categories NO / YES. ${ }^{4}$

*Self-identification with Spain: admits the categories NO / YES.

The distribution of the sample according to the independent variables is shown in Table 1.

TABLE 1 NEAR HERE

Instruments

The results obtained are the result of a completed questionnaire about attitudes and selfidentification, where socio-demographic items were included. 
In order to obtain indicators about language attitudes, questionnaires elaborated by the Service for Teaching of Catalan (Servei d'Ensenyament del Català) (SEDEC) based on the works by Sharp, Price, Francis and Davis (1973) were adapted. These have been successfully used before in other works within the context of immigration (Huguet, Janés and Chireac 2008; Madariaga, Huguet and Lapresta 2013; Navarro and Huguet 2005). Their reliability was tested by a test-retest at an interval of two months between the tests, obtaining a correlation of $\mathrm{r}=.703(\mathrm{p}<.0001)$

The questionnaire is composed of twenty statements with dichotomous reply (YES/NO), ten for each language. Each of them is given a +1 / -1 score, depending on whether the answer is favourable or unfavourable towards that particular language. Thus, through score addition a scale ranging from -10 (completely unfavourable attitudes) to +10 (completely favourable attitudes) is obtained, 0 signalling neutral attitudes.

\section{Treatment of results}

With the aim of observing in a disaggregated manner the impact of the place of birth and the self-identification with Catalonia and Spain on language attitudes towards Catalan and Spanish, statistical descriptions (Mean and Standard Deviation) and mean comparison tests have been used for the data analysis. In this case, ANOVA and the Bonferroni test were used; the latter for more in-depth analysis when the first result is significant.

As a second stage, the General Linear Models (GLM) have been carried out to establish the joint effect, specify the interaction and the importance of the place of birth and the self- 
identification with Catalonia and Spain, in the explanation of the attitudes towards Catalan and Spanish variance.

These analyses have been used both with the total sample and with the subjects that show the most and the least positive attitudes.

Based on a previous data study regarding manifested language attitudes and their distribution, the young people in the fourth quartile, scoring 7 and more, were considered those with the best attitudes, while those scoring between 2 and -10 were considered the least favourable, corresponding with the first quartile.

\section{Results}

With the aim of obtaining the maximum clarity, results are presented in three sections. The first section contains an analysis of the total sample, the second section focuses on the young people who showed the most positive attitudes, and the third section focuses on the young people who showed the least positive attitudes.

Attitudes towards Catalan and Spanish, Place of Birth and Self-identification with Catalonia and Spain. Global Findings.

Taking the whole sample into consideration, the mean of attitudes towards Catalan among immigrant young people is favourable, with a mean score of 4.5469, and a standard deviation of 4.7845. In the case of Spanish the mean is higher: 7.009 ( $S D=3.0837)$, the difference between them being statistically significant $\left(\mathrm{t}_{(308)}=-7.222 ; \mathrm{p}<.000\right){ }^{5}$ 
In the case of attitudes towards Catalan, both the place of birth and self-identification with Catalonia have a great impact. Moroccans were those showing the most favourable attitudes ( $M=6.5176 ; S D=3.2936)$, followed by those from Ecuador $(M=5.3455 ; S D=4.2523)$ and those from the rest of Latin America ( $M=3.2959$; $S D=5.1945)$. Moreover, the least favourable attitudes from the latter group are statistically significant with respect to the rest $\left(\mathrm{F}_{\text {Latin America-Ecuador(2,306) }}=15.005 ; \mathrm{p}=.012 / \mathrm{F}_{\text {Latin America-Morocco(2,306) }}=15.005 ; \mathrm{p}<.000\right)$.

Likewise, those who self-identify with Catalonia have more positive attitudes towards the Catalan language $(M=6.3621 ; S D=3.4357)$ compared with those who do not $(M=2.2074$; $\mathrm{SD}=5.2520)$; again, the differences are significant $\left(\mathrm{F}_{(1,307)}=70.201 ; \mathrm{p}<.000\right)$.

Regarding attitudes towards Spanish, only the place of birth has an impact, in the sense that those born in Ecuador $(\mathrm{M}=8.0727 ; \mathrm{SD}=2.2348)$ and other Latin American countries ( $\mathrm{M}=7.3373 ; \mathrm{SD}=2.5492)$ develop more favourable attitudes than those born in Morocco $(M=5.6706 ; S D=3.9862)$. These differences are significant $\quad\left(F_{\text {Morocco-Ecuador }(2,306)}=13.205\right.$;

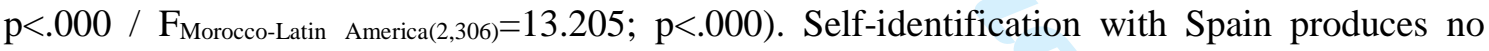
differences.

These general results point to both variables having individual effects on attitudes towards Catalan. Only the place of birth has effects on attitudes towards Spanish. It is therefore not possible to elucidate their joint interaction, or which of them, if any, has more weight in the explanation of the differences found. 
The General Linear Model (GLM) (Table 2) carried out for attitudes towards Catalan indicates that the model itself explains a significant proportion of the variance attitudes towards Catalan (for the signification of the Model Corrected; $\mathrm{p}<.000$ ). It also informs us that the variables place of birth and self-identification with Catalonia have an individual effect, as has been seen above. However, the most interesting is that the interaction between place of birth and self-identification with Catalonia is not significant, which implies that they do not have a joint effect.

TABLE 2 NEAR HERE

An Interaction Graph explains the articulation of the influence of the variables (Figure 1). As a general rule, the pattern of attitudinal behaviour is rather similar; although attitudes towards Catalan may be more or less positive among groups, those who identify more with Catalonia show, in all cases, more positive attitudes than those who do not.

FIGURE 1 NEAR HERE

Regarding Spanish, results from both the GLM and the Interaction Graph (Table 3 and Figure 2) indicate yet again that only the country of birth has an incidence on attitudes towards Spanish,. The model on the whole is significant, as is the effect of country of birth, while self-identification with Spain and the intersection between the two variables are not. 
TABLE 3 AND FIGURE 2 NEAR HERE

Attitudes towards Catalan and Spanish, Place of Birth and Self-identification with Catalonia and Spain. Young people with the MOST favourable attitudes

Among those showing the most positive attitudes towards Catalan, the first difference in respect of the total sample is that their attitudes are not influenced by the place of birth. ${ }^{6}$

However, the introduction of self-identification with Catalonia does produce some variations. In this case, those who do not identify at all show a mean attitude value of 8.3750 ( $S D=1.0080)$, while those who do, show a mean attitude value of 8.9541 ( $S D=1.0218)$, the difference being statistically significant $\left(\mathrm{F}_{(1,139)}=7994 ; \mathrm{p}<.005\right)$.

The GLM including both variables confirms these results, self-identification with Catalonia being the only significant variable (Table 4).

TABLE 4 NEAR HERE 
The Interaction Graph also confirms that, among those with the most positive attitudes towards Catalan, these attitudes are more related with their identification with Catalonia than with their place of birth (Figure 3).

FIGURE 3 NEAR HERE

None of the two variables produces significant differences for those who show the most positive attitudes towards Spanish; the means of those born in Ecuador, other Latin American countries and Morocco are 9.1463 (SD=0.9889), $8.9159 \quad(\mathrm{SD}=1.0290)$ and 9.0769 $(\mathrm{SD}=0.9836)$ respectively. The mean of those who do not identify at all with Spain is 8.9306 ( $\mathrm{SD}=1.0254)$ and the mean of those who do identify with Spain is 9.0435 ( $\mathrm{SD}=1.0034){ }^{7}$

\section{Attitudes towards Catalan and Spanish, Place of Birth and Identification with Catalonia and Spain. Young people with the LEAST favourable attitudes}

In a manner similar to the subjects with the most favourable attitudes towards Catalan, those who develop the least favourable attitudes towards Catalan are not influenced by the place of birth.8

However, self-identification is again an element which introduces variations in attitudes, obtaining the least favourable attitudes from those who do not identify at all with Catalonia (M=2.1159; $S D=3.5043)$ compared with those who do identify ( $M=-0.5556 ; \quad S D=2.6937)$, with statistical significance $\left(\mathrm{F}_{(1,94)}=4.339 ; \mathrm{p}=.040\right)$. 
Prevalence of self-identification is stated again in the GLM (Table 5), as well as in the Interaction Graph (Figure 4).

TABLE 5 AND FIGURE 4 NEAR HERE

Focusing now on the case of young people who show the least favourable attitudes towards Spanish, neither variable introduces significant differences, just like with those showing the most favourable attitudes. ${ }^{9}$

\section{Conclusions and Discussion}

The effect of the place of birth and self-identification on attitudes is obvious and complex.

As a general rule, language attitudes towards Catalan and Spanish of young people born in Morocco, Ecuador and other countries of Latin America are positive, although more in the case of Spanish. Those who develop the most favourable attitudes towards Spanish are born in Ecuador and other Latin American countries compared to those born in Morocco. On the contrary, the most positive attitudes towards Catalan are shown by those born in Morocco as opposed to those coming from Latin American countries other than Ecuador. In general terms, these results are in line with previous studies carried out in Catalonia (Huguet and Janés 2005; Huguet, Janés and Chireac 2008; Madariaga, Huguet and Lapresta 2013) and in other bilingual places in Spain, especially the Basque Country (Ibarrarán, Lasagabaster and Sierra 
2008; Rojo, Madariaga and Huguet, 2010). Moreover, they are also in line with other studies that do not specifically focus on language attitudes, and show the heterogeneity in language preferences and self-identifications of the Latin American group (Alarcón, Parella and Yiu 2014; Portes, et al. 2012, among others). This issue certainly requires further in-depth qualitative and quantitative studies.

Moreover, self-identification with Catalonia produces better attitudes towards Catalan, something which does not happen with self-identification with Spain and attitudes towards Spanish.

Looking into the case of attitudes towards Catalan at the level of the whole sample, the effect of both conditions can be proven separately, but when considered jointly, selfidentification with Catalonia is the one that modulates attitudes towards Catalan. This is more obvious in the case of young people with the most and the least favourable attitudes.

All this seems to suggest that the place of origin may produce attitudes towards Catalan to be more or less favourable, but what makes attitudes improve is a high degree of selfidentification with Catalonia. Obviously, additional studies are required to further investigate this issue.

Nevertheless, when delving into the case of attitudes towards Spanish, only the place of origin produces this effect and only at the level of the whole sample. Self-identification with Spain or the place of origin has no effects on subjects who show the most and the least favourable attitudes. 
These points have important repercussions at the theoretical level and in the Catalan context.

The fact that the improvement of language attitudes towards Catalan is tied to selfidentification with Catalonia is connected to the role given to this language within the project of coexistence to be constructed; a project with a multilingual approach but with Catalan as its symbol par excellence (Fishman 1977), with a communicative function and also a participatory function (name deleted to maintain the integrity of the review process 2006; name deleted to maintain the integrity of the review process 2008). A possible effect is that the development of a feeling of belonging is also expressed through the language and is manifested in the language attitudes (Trenchs and Newman 2009; Trenchs, Patiño and Ng 2008; Woolard 1991).

Language attitudes towards Spanish find themselves in a completely different situation. In spite of the lack of the necessary in-depth studies on this process, elements such as the international prestige of the language, its instrumental value, its important social presence in Catalonia (Galindo 2008; Vila-Moreno 2004) and family language factors (Madariaga, Huguet and Lapresta 2013) seem to produce positive attitudes towards it.

Taking into consideration these conclusions, and evidently without overlooking the place of origin, work needs to be continued to enable young people's self-identification with Catalonia, especially, a self-identification that implies the development of a sense of belonging and emotional ties with the country (Haines 2007; Portes, Vickstrom and Aparicio, 2012). In the case of the children of immigrants, research carried out both in the Catalan context and in others, shows that this process is more effective the moment a social value is 
given by the host society to the languages and cultures brought by these young people (Coelho, Oller and Serra 2013; Cummins 2001; Huguet, Janés and Chireac 2008; Lapresta et al. 2010; Trenchs and Patiño 2013).

Moreover, given the weight of language attitudes in any policy regarding languages (Lewis 1981), it would be a simplification to focus only on one language and only on strictly linguistic measures in multilingual contexts. The present time is not unfavourable in Catalonia. Largely thanks to the policies on language, education, reception and integration currently in force, attitudes towards Catalan are mainly favourable. But this means that work needs to be done at the non-linguistic and linguistic levels; the latter being as important as those seeking selfidentification with a project of multilingual coexistence, both for the children of immigrants and for the rest of the society.

\section{Acknowledgements}

This work was supported by the Ministry of Economy and Competitiveness of the Government of Spain [grant number EDU2014-54093-R] and Government of Catalonia - Agència de Gestió d'ajuts Universitaris i de Recerca (AGAUR) [grant number 2014 SGR 208].

\section{Notes}

1. By using the denominations 'descendants of immigrants', 'young people of immigrant origin and 'children of migrations' in this document, we do not mean to identify immigration as a personal heritable attribute. On the contrary, in our conceptualisation these young people are the protagonist of their own existence and identity constructions, differentiated from those of their parents. 
2. Schools were chosen with the advice of the Catalan educational authority for the presence of immigrants. Schools are: two in the city of Barcelona, two in the province of Barcelona, one in the city of Girona, one in the province of Girona, one in the city of Tarragona, one in the province of Tarragona, one in the city of Lleida and one in the province of Lleida.

3. All the nationalities included in this category correspond to Spanish-speaking countries

4. This variable is the result of recoding the question: 'To what degree do you feel Catalan?' with the response options 'Not at all' / 'A little'/ 'Somewhat' / 'Very much'. Given the subjectivity of the responses, it was decided to differentiate between 'No / Yes'. 'No' includes all the individuals that responded 'Not at All'; and 'Yes' includes all the rest. This codification or adaptation, has been successfully used in numerous works that analyse selfidentification and language preferences of the descendants of immigrants within the Catalan and Spanish context, such as those by Gualda (2010), Portes, Celaya, Vickstrom and Aparicio (2012), Portes Vickstrom and Aparicio (2012) and Alarcón and Parella (2013). The same procedure was applied to the variable 'Self-identification with Spain'.

5. Student's T test has been used only in this case for the comparison of means, as the mean values of the same group are compared in two variables.

6. The mean of those born in Ecuador is $8.8182(\mathrm{SD}=1.1396)$, the mean of those born in the rest of Latin America 8.6667 ( $S D=0.9712)$, and the mean of those born in Morocco 8.9348 $(\mathrm{SD}=1.1035)$. 
7. The non-significance of any of the variables considered makes bivariate analysis unnecessary.

8. The group born in Ecuador reach a mean of -1.7273 ( $S D=3.4085)$, those born in the rest of Latin American countries reach a mean of $-1.9429(\mathrm{SD}=3.4636)$ and those born in Morocco $0.0000(\mathrm{SD}=2.0000)$

9. The mean of those born in Ecuador is $1.0000(\mathrm{SD}=1.4142)$, the mean of those coming from other Latin American countries is $0.8000(\mathrm{SD}=1.8738)$ and the mean of those born in Morocco is -0.6111 ( $S D=2.3044)$. The mean of those who do not self-identify with Spain at all is $-0.2857(\mathrm{SD}=2.6903)$ and the mean of those who do is $0.0435(\mathrm{SD}=2.0775)$. 


\section{References}

Alarcón, Amado, and Sonia Parella. 2013. "Linguistic Integration of the Descendents of Foreign Immigrants in Catalonia.” Migraciones Internacionales 7(1): 101-130.

Alarcón, Amado, Sonia Parella and Jessica Yiu. 2014 "Educational and Occupational Ambitions among the Spanish 'Second Generation’: The Case of Barcelona.” Journal of Ethnic and Migration Studies 40 (10): 1614-1636. doi: 10.1080/1369183X.2013.831550.

Baker, Colin. 1992. Attitudes and Language. Clevedon, UK: Multilingual Matters.

Castelan, Aaron, and Howard Giles. 1997. “Understanding Language Attitudes: Exploring Listener Affect and Identity.” Language and Communication 17(3), 195-217. doi: 10.1016/S0271-5309(97)00016-5.

Coelho, Elisabeth, Judit Oller, and Josep M. Serra. 2013. Lenguaje y Aprendizaje en el Aula Multilingüe. Un Enfoque Práctico. Barcelona: ICE-HORSORI.

Cummins, Jim. 2001. "Bilingual Children's Mother Tongue: Why Is It Important for Education?” Sprogforum 7 (19): 15-20. doi: 10.1080/13670059808667672.

Edwards, John. 2009. Language and Identity. Cambridge, UK: Cambridge University Press.

Fishman, Joshua A. 1977. “Language and Ethnicity.” In Language and ethnic relations, edited by Howard Giles and Bernard Saint Jaques, 15-57. Oxford, UK: Pergamon. 
Galindo, Mireia. 2008. Les llengües en Joc, el Joc entre Llengües: L’ús Interpersonal del Català entre els Infants i Joves de Catalunya [Languages in play, the game of languages: Interpersonal use of Catalan among children and youth in Catalonia]. Lleida: Pagès Editors.

Garrett, Peter. 2010. Attitudes to Language. Cambridge, UK: Cambridge University Press.

Generalitat de Catalunya. 2007. Pla per a la Llengua i la Cohesió Social. [Plan for the Language and Social Cohesion]. Barcelona: Generalitat de Catalunya.

Generalitat de Catalunya. 2009. Pla per a la Llengua i la Cohesió Social. Educació i Convivència Intercultural [Plan for the Language and Social Cohesion. Education and Intercultural Coexistence]. Barcelona: Generalitat de Catalunya.

Generalitat de Catalunya. 2013. Pla de Ciutadania i de les Migracions: Horitzó 2016 [Plan for Citizenship amd Migrations: Horizon 2016]. Barcelona: Generalitat de Catalunya.

Generalitat de Catalunya - Departament d’Ensenyament 2015. Statistics. Accessed July 15, 2015. http://ensenyament.gencat.cat/ca/departament/estadistiques/dades-curs-actual/eso/

Gualda, Estrella. 2010. “La Segunda Generación y la Integración Social de Adolescentes y Jóvenes Inmigrantes e Hijos de Inmigrantes”. In La Segunda Generación de Inmgrantes en Huelva: Estudio HIJAI, edited by Estrella Gualda, 19-26. Xàtiva: Mateu Editores. 
Haines, David W. 2007. “Ethnicity’s Shadows: Race, Religion and Nationality as Alternative Identities among Recent United States Arrivals.” Identities 14: 285-312. doi: 10.1080/10702890601162773.

Hogg, Michael A., and Joanne R. Smith. 2007. “Attitudes in Social Context: A Social Identity Perspective.” European Review of Social Psychology 18: 89-131. doi: 10.1080/10463280701592070.

Huguet, Àngel, and Judit Janés. 2005. “Immigrant Children in Bilingual Societies. Attitudes towards Languages by Newcomers to Catalonia.” Cultura \& Educación 17 (4): 309-321. doi: 10.1174/113564005775133748.

Huguet, Ángel, Judit Janés, and Silvia Chireac. 2008. “Mother Tongue as a Determining Variable in Language Attitudes: The Case of Immigrant Latin American Students in Spain.” Language and Intercultural Communication 8 (4): 246-260. doi: 10.1080/14708470802303082.

Ibarrarán, Amaia, David Lasagabaster, and José Ma. Sierra. 2008. "Multilingualism and Language Attitudes: Local versus Immigrant Students’ Perceptions.” Language Awareness 17 (4): 326-341. doi: 10.2167/la475.0

Lewis, E. Glyn. 1981. Bilingualism and Bilingual Education. Oxford, UK: Pergamon. 
Madariaga, Jose $\mathrm{M}^{\mathrm{a}}$, Ángel Huguet, and Cecilio Lapresta. 2013. “Actitud, Presión Social y Educación Inclusiva en Aulas con Diversidad Lingüística y Cultural.” Educación XX1 16 (1): 305-328.

Navarro, José L., and Ángel Huguet. 2005. El Conocimiento de la Lengua Castellana en Alumnado Inmigrante Escolarizado en $1^{\circ}$ de ESO: Un Estudio Empírico. Madrid: CIDEMinisterio de Educación y Ciencia.

Newman, Michael, Mireia Trenchs, and Shukhan Ng. 2008. "Normalizing Bilingualism: The Effects of the Catalonian Linguistic Normalization Policy One Generation After.” Journal of Sociolinguistics 12 (3): 306-333. doi: 10.1111/j.1467-9841.2008.00369.x

Newman, Michael, Adriana Patiño, and Mireia Trenchs. 2013. "Linguistic Reception of Latin American Students in Catalonia and their Responses to Educational Language Policies.” International Journal of Bilingual Education and Bilingualism 16 (2): 195-209. doi: 10.1080/13670050.2012.720669.

Oller, Judit. 2010. "Effects of the sociolinguistic context in the knowledge of the school language by students coming from foreign countries at the end of sixth year primary education: the case of Catalonia. In Multilingualism and educational practice. 6th Symposium: language, education and immigration, edited by ICE Josep Pallach, 106-114. Girona: Universitat de Girona.

Oller, Judit and Ignasi Vila. 2010. "Effects of Sociolinguistic Environment and Length of Residence on the Linguistic Performance in Catalan and Spanish of Sixth Grade 
Immigrant Pupils in Catalonia”. Sociolinguistic Studies 4 (1): 63-84. doi: 10.1558/sols.v4i1.63.

Portes, Alejandro, Erik Vickstrom, and Rosa Aparicio. 2012. "Coming of Age in Spain: The Self-identification, Beliefs and Self-esteem of the Second Generation.” British Journal of Sociology 62 (3): 387-417. doi: 10.1111/j.1468-4446.2011.01371.x

Portes, Alejandro, Adrienne Celaya, Erik Vickstrom and Rosa Aparicio. 2012. "Who are we? Parental Influences on Self-identities and Self-esteem of Second Generation Youths in Spain.” Revista Internacional de Sociología 70 (1): 9-37. doi:10.3989/ris.2011.09.26.

Rojo, Vanesa, Jose Mª Madariaga, and Ángel Huguet. 2010. "Immigrant and Native Secondary Education Students' Linguistics Attitudes towards the Basque and Spanish Languages” Cultura \& Educación 22 (1): 85-97. doi: 10.1174/113564010790935231

Sharp, Derrick, Beryl Thomas, Eurwen Price, Gareth Francis and, Iwan Davis. 1973. Attitudes to Welsh and English in the Schools of Wales. Basingstoke/Cardiff, U.K.: McMillan, University of Wales Press.

Solé, Carlota. 1981. La Integración Sociocultural de los Inmigrantes en Cataluña. Madrid: Centro de Investigaciones Sociológicas.

Spanish Statistical Office (Instituto Nacional de Estadística). 2015. “INEBase”. Accessed July 15, 2015. http://www.ine.es/inebmenu/indice.htm\#nogo. 
Tajfel, Henry, and John C. Turner. 1986. "The Social Identity Theory of Intergroup Behaviour.” In Psychology of Intergroup Relations, edited by Stephen Worchel and William G. Austin, 7 - 24. Chicago, ILL: Nelson-Hall.

Trenchs, Mireia, and Michael Newman. 2009. "Diversity of Language Ideologies in SpanishSpeaking Youth of Different Origins in Catalonia.” Journal of Multilingual and Multicultural Development 30 (6): 509-524. doi: 10.1080/01434630903147914.

Trenchs, Mireia, and Adriana Patiño. 2013. "Language Attitudes of Latin American Newcomers in Three Secondary School Reception Classes in Catalonia.” In Teaching Languages in a Multilingual Context: The Catalan Case, edited by Joaquim Arnau, 49-71. Bristol, UK: Multilingual Matters/Institut d’Estudis Catalans.

Turell, Maria Teresa. 2001. “Spain’s Multilingual Makeup: Beyond, Within, and Across Babel.” In Multilingualism in Spain, edited by Maria Teresa Turell, 1-57. Clevedon, UK: Multilingual Matters.

Ubalde, Josep. 2013. “L’adopció d’actituds lingüístiques: un estudi transversal sobre les actituds vers el català en adolescents de Catalunya i la Franja” [Language attitude adoption: a cross-sectional study on attitudes towards Catalan among adolescents from Catalonia and La Franja.] Treballs de Sociolingüística Catalana 23: 287-302. doi: 10.2436/20.2504.01.61.

Vila-Moreno, F. Xavier. 2004. "Hora de fer balanç? Elements per Valorar les Polítiques Lingüístiques a Catalunya en el període constitucional.” [Time for Taking Stock? 
Elements for Assessing Language Policies in Catalonia during the Constitutional Period.] Revista de Llengua i Dret 41: 243-286.

Vila-Moreno, Francesc Xavier, and Mireia Galindo. 2009. “El Sistema de Conjunció en Català a Catalunya: Impacte sobre els usos.” [The Linguistic Model of Joint Teaching in Catalan in Catalonia: Impact on Usage] Treballs de Sociolingüística Catalana 20: 21-69.

Woolard, Kathryn A. 1989. Double talk: Bilingualism and the politics of ethnicity in Catalonia. Stanford, CA: Stanford University Press.

Woolard, Kathryn A. 1991. "Linkages of Language and Ethnic Identity: Changes in Barcelona, 1980-1987.” In Language and Ethnicity: Focus Schrift in Honor of Joshua A. Fishman on the Occasion of his 65th Birthday, II, edited by James R. Dow, 61-81. Amsterdam, The Netherlands: Benjamins.

Woolard, Kathryn A., and Tae J. Gang. 1990. "Changing Language Policies and Attitudes in Autonomous Catalonia.” Language in Society 19: 311-330. doi:10.1017/S0047404500014536.

Woolard, Kathryn A., and Bambi Schieffelin. 1994. "Language ideology.” Annual Review of Anthropology 23: 55-82. doi: 10.1146/annurev.an.23.100194.000415 
Table 1. Sample distribution according to the Place of Birth and Self-identification with

Catalonia and Spain. Absolute Frequencies and Percentages.

\begin{tabular}{|c|c|}
\hline \multicolumn{2}{|l|}{ Place of Birth } \\
\hline Morocco & $27.50 \%(85)$ \\
\hline Ecuador & $17.80 \%(55)$ \\
\hline Other Latin American Countries & $54.70 \%(169)$ \\
\hline Argentina & $9.90 \%(29)$ \\
\hline Bolivia & $9.90 \%(29)$ \\
\hline Colombia & $10 \%(31)$ \\
\hline Cuba & $0.80 \%(3)$ \\
\hline E1 Salvador & $1.50 \%(5)$ \\
\hline Honduras & $2.40 \%(8)$ \\
\hline Penu & $5.70 \%(18)$ \\
\hline Dominican Republic & $5.50 \%(17)$ \\
\hline Uruguay & $2.40 \%(8)$ \\
\hline Venezuela & $2.80 \%(9)$ \\
\hline Chile & $3.80 \%(12)$ \\
\hline
\end{tabular}

\begin{tabular}{lll} 
& $\begin{array}{l}\text { Self-identification } \\
\text { Catalonia }\end{array}$ & $\begin{array}{l}\text { Self-identification } \\
\text { Spain }\end{array}$ \\
No & $43.69 \%(135)$ & $36.89 \%(114)$ \\
\hline Yes & $56.31 \%(174)$ & $63.11 \%(195)$ \\
\hline
\end{tabular}


Table 2. Univariate General Linear Model. Dependent variable: Attitudes towards Catalan.

Fixed factors: Self-Identification with Catalonia and Place of Birth. Total Sample.

\begin{tabular}{lcc} 
& $\mathrm{F}$ & Sig. \\
\cline { 2 - 3 } Corrected Model & 19.164 & $\mathbf{. 0 0 0 ^ { * * }}$ \\
\hline Interceipt & 361.364 & $\mathbf{. 0 0 0 ^ { * * }}$ \\
\hline Self-identification Catalonia & 74.224 & $\mathbf{. 0 0 0 ^ { * * }}$ \\
\hline Place of Birth & 8.500 & $.000^{* *}$ \\
\hline Self-identification Catalonia*Place of Birth & 2.297 & .102 \\
\hline${ }^{*} \mathrm{p}<.05$ & & \\
${ }^{* *} \mathrm{p}<.01$ & & \\
\end{tabular}


Table 3. Univariate General Linear Model. Dependent variable: Attitudes towards Spanish. Fixed factors: Self-Identification with Spain and Place of Birth. Total Sample.

\begin{tabular}{lcc} 
& $F$ & Sig. \\
\cline { 2 - 3 } Corrected Model & $\mathbf{5 . 3 2 1}$ & $\mathbf{. 0 0 0 ^ { * * }}$ \\
\hline Interceipt & 1708.596 & $\mathbf{. 0 0 0 ^ { * * }}$ \\
\hline Self-identification Spain & .001 & .971 \\
\hline Place of Birth & 13.094 & $\mathbf{. 0 0 0 ^ { * * }}$ \\
\hline Self-identification Spain*Place of Birth & .209 & .812 \\
\hline${ }^{*} \mathrm{p}<.05$ & & \\
${ }^{* *} \mathrm{p}<.01$ & & \\
& &
\end{tabular}


Table 4. Univariate General Linear Model. Dependent variable: Attitudes towards Catalan. Fixed factors: Self-Identification with Catalonia and Place of Birth. Young People with the MOST favourable attitudes towards Catalan.

\begin{tabular}{lcc} 
& $\mathrm{F}$ & Sig. \\
\cline { 2 - 3 } Corrected Model & 1.599 & .166 \\
\hline Interceipt & 8740.560 & $\mathbf{. 0 0 0 ^ { * * }}$ \\
\hline Self-identification Catalonia & 6.323 & $.013^{*}$ \\
\hline Place of Birth & .834 & .437 \\
\hline Self-identification Catalonia*Place of Birth & .003 & .997 \\
\hline${ }^{*} \mathrm{p}<.05$ & & \\
${ }^{* *} \mathrm{p}<.01$ & &
\end{tabular}


Table 5. Univariate General Linear Model. Dependent variable: Attitudes towards Catalan. Fixed factors: Self-Identification with Catalonia and Place of Birth. Young People with the LEAST favourable attitudes towards Catalan.

\begin{tabular}{lcc} 
& $F$ & Sig. \\
\cline { 2 - 3 } Corrected Model & 16.76 & .149 \\
\hline Interceipt & 24.166 & $\mathbf{. 0 0 0 ^ { * * }}$ \\
\hline Self-identification Catalonia & 58.32 &. $\mathbf{0 1 8 ^ { * }}$ \\
\hline Place of Birth & 10.43 & .357 \\
\hline Self-identification Catalonia*Place of Birth & .230 & .795 \\
\hline${ }^{*} \mathrm{p}<.05$ & & \\
${ }^{* *} \mathrm{p}<.01$ & & \\
\end{tabular}




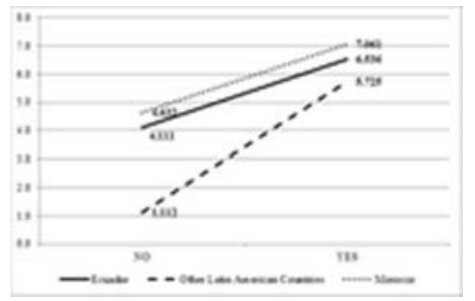

Figure 1. Marginal Estimated Means of Attitudes toward Catalán according to Self-I dentification and Place of Birth (Total Sample) $14 \times 9 \mathrm{~mm}(300 \times 300 \mathrm{DPI})$ 


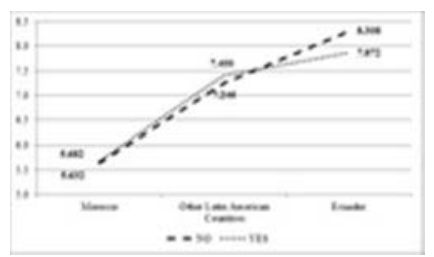

Figure 2. Marginal Estimated Means of Attitudes toward Spanish according to Self-identification and Place of Birth (Total Sample).

$13 \times 7 \mathrm{~mm}(300 \times 300 \mathrm{DPI})$ 


\section{Page 37 of 38}

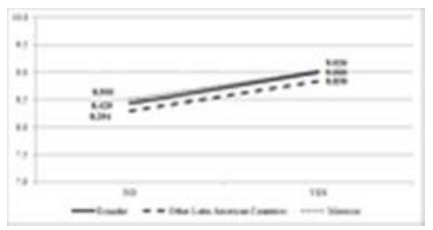

Figure 3. Marginal Estimated Means of MOST Favourable Attitudes towards Catalan according to Selfidentification and Place of Birth.

$13 \times 7 \mathrm{~mm}(300 \times 300 \mathrm{DPI})$ 


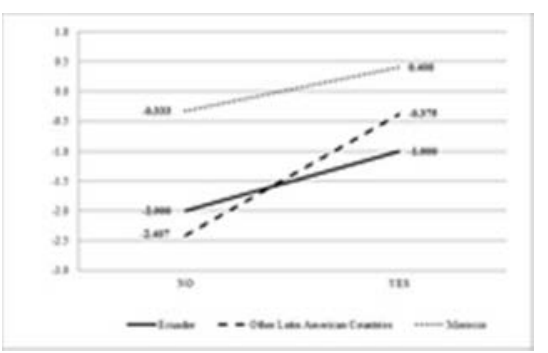

Figure 4. Marginal Estimated Means of LEAST Favourable Attitudes towards Catalan according to Selfidentification and Place of birth.

$17 \times 10 \mathrm{~mm}(300 \times 300 \mathrm{DPI})$ 